\title{
Cost Comparison of Drainage Channel Construction Considering Uncertainty of Rainfall Distribution
}

\author{
Intan Supraba ${ }^{1, *}$, Istiarto $^{1}$, Radianta Triatmadja ${ }^{1}$ \\ ${ }^{1}$ Department of Civil and Environmental Engineering, Universitas Gadjah Mada, Yogyakarta, INDONESIA \\ ${ }^{*}$ Corresponding authors: intan.supraba@ugm.ac.id
}

SUBMITTED 26 September 2018 REVISED 23 December 2018 ACCEPTED 13 January 2019

\begin{abstract}
Rainfall data is the main parameter to design drainage channel. The accuracy of rainfall data determines the accuracy of peak discharge estimation that is used for designing the drainage channel for flood mitigation purpose. The previous study presented that uncertainty of peak discharge is associated with the uncertainty of rainfall distribution and uncertainty of water holding capacity. The main purpose of this study is for understanding the sensitivity of rainfall data by comparing the estimated cost to construct drainage channel based on different values of peak discharges using two different rainfall data set which one rainfall data is created by considering $10 \%$ uncertainty of rainfall distribution. This study area is located on Plampang, Sumbawa Besar, West Nusa Tenggara. Results showed that the total cost to construct drainage channel increased by $15 \%$ if considering $10 \%$ uncertainty of rainfall.
\end{abstract}

KEYWORDS Uncertainty of rainfall distribution; cost estimation; drainage channel construction

(C) The Author(s) 2018. This article is distributed under a Creative Commons Attribution-ShareAlike 4.0 International license.

\section{INTRODUCTION}

One of the main research target in hydrology is to increase the accuracy of peak discharge that is highly influenced by the accuracy of rainfall data. The accuracy of peak discharge estimation affects the design of a drainage channel for flood mitigation purpose that finally gives impact to the construction costs. Rain gauges measure the rainfall intensity near the land surface, but the accuracy is depending on location and density of rain gauges. The measured rainfall amounts are influenced by several factors such as wind, snowfalls, station relocation, and change of the sensors (Burcea, et al., 2012). Rain gauges based rainfall intensity measurements can be biased by factors like wind and evaporation in the range of 1020\% (Cheval, et al., 2011). The uncertainty of peak runoff height increases with the increment of uncertainty associated with rainfall pattern, and uncertainty of water holding capacity needs to be included in the quantification of the uncertainty of peak runoff height (Supraba \& Yamada, 2015). The uncertainty of peak runoff associated with water holding capacity is more dominant when the uncertainty of rainfall distribution is $10 \%$, and it is less dominant when the uncertainty of rainfall distribution is $20 \%$ (Supraba, 2015).
This study area is located on Plampang, Sumbawa Besar, West Nusa Tenggara where a steam electric power station will be built. The secondary daily rainfall data was obtained from Empang Station that was issued by Stasiun Klimatologi Kelas I West Lombok NTB (Lembaga Kerjasama Fakultas Teknik UGM, 2016).

The main purpose of this study is for understanding the sensitivity of rainfall data by comparing the values of peak discharges using two different rainfall data set in which one rainfall data set is created by considering $10 \%$ uncertainty of rainfall. Thus, a comparison of the estimated cost to construct a drainage channel using two different rainfall data set is presented in this study.

\section{METHODOLOGY}

\subsection{Data}

In this study, the annual maximum daily rainfall data from 1998 to 2015 obtained from Empang Station is called the original rainfall data. Another rainfall data that is created by considering $10 \%$ uncertainty is called uncertainty rainfall data. Original rainfall and uncertainty rainfall data are presented in Figure 1. 


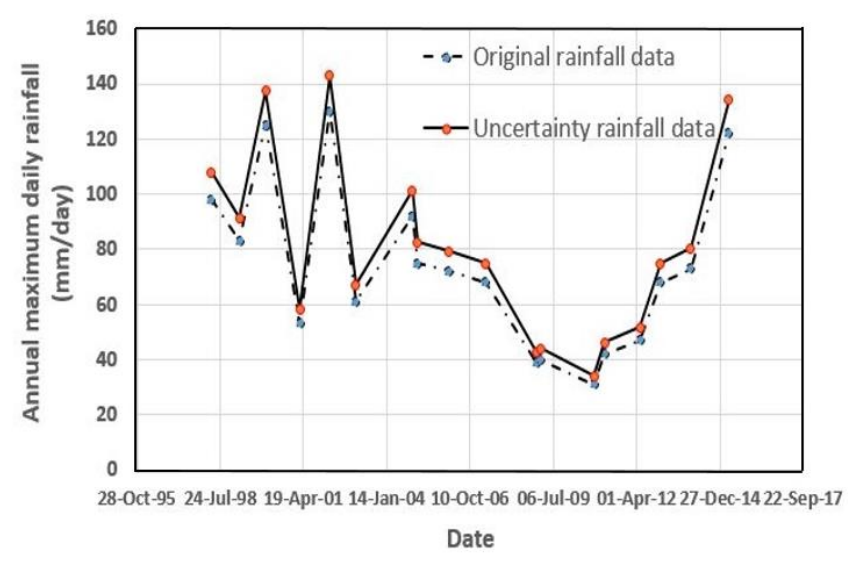

Figure 1. Rainfall data

\subsection{Peak Discharge Estimation}

Design rainfall for different return period was obtained by doing frequency analysis based on Gumbel, LogNormal, Normal, and Log Pearson III probability distributions. After obtaining design rainfall, the rainfall intensity can be calculated by using the Mononobe equation as follows:

$$
I=\frac{R_{24}}{24}\left(\frac{24}{t_{c}}\right)^{2 / 3}
$$

which is $I$ is rainfall intensity ( $\mathrm{mm} /$ hour), $R_{24}$ is annual maximum daily rainfall for a certain return period $\left(\mathrm{mm} /\right.$ day), and $t_{c}$ is a time of concentration (hour). $t_{c}=0.0195 L^{0.77} S^{-0.385}$

With $L$ is channel length (m) and $S$ is slope.

Thus, after calculating rainfall intensity for different return period, the peak discharge is calculated by using the Rational Method as follows:

$Q=0.278 C I A$

which is $Q$ is peak discharge $\left(\mathrm{m}^{3} / \mathrm{s}\right), C$ is surface runoff coefficient and $A$ is catchment area $\left(\mathrm{km}^{2}\right)$

\subsection{Catchment Area}

The catchment area consists of 4 sub-catchments is shown in Figure 2. Rainfall at sub-catchment 1 will be drained out to the east drainage channel, while rain falls at sub-catchments 2 and 3 will be drained out to the south channel, whereas rainfall at sub-catchment 4 will be drained out to the west drainage channel.

\subsection{Land Use}

Land use map was obtained from the earth map produced by Badan Informasi Geospasial (see Figure 2). From Figure 2, it can be seen that the land use of the proposed location is covered up by shrubbery. The runoff coefficient for shrubbery based on Watershed Modelling System V.6.0 Software Manual is 0.42.

Time of concentration is calculated by using the Kirpich method as follows:
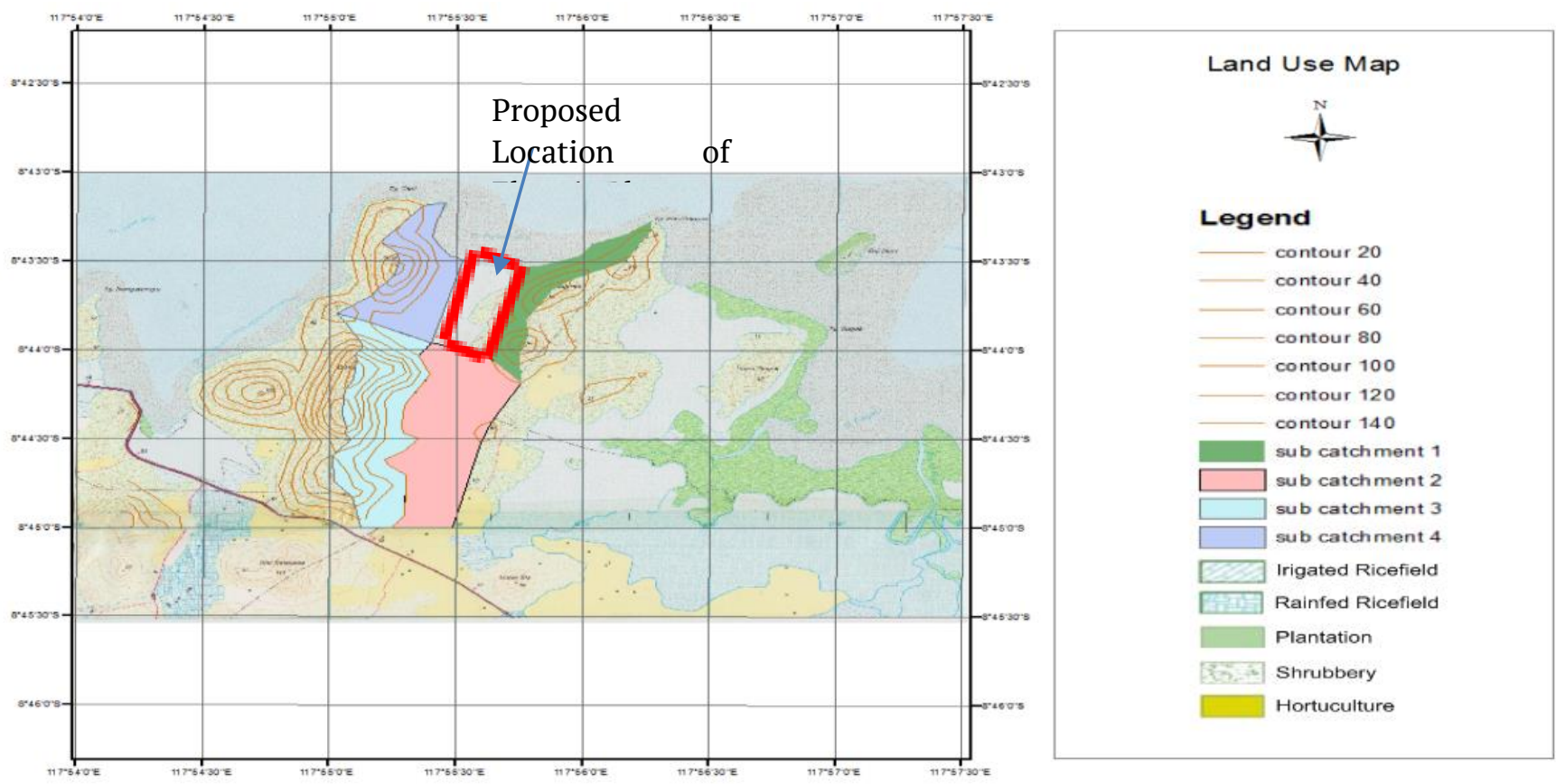

Figure 2. Catchment area and land use map. 


\section{RESULTS}

By using Equation (3), the comparison of calculated peak discharges using original rainfall data and by considering $10 \%$ uncertainty of rainfall based on 50 years return period using Log Pearson III probability distribution is presented at Table 1.

Table 1. Comparison of peak discharge values for perimeter drainage channel

\begin{tabular}{lll}
\hline $\begin{array}{l}\text { Perimeter } \\
\text { drainage } \\
\text { channel }\end{array}$ & $\begin{array}{l}\text { Peak discharge } \\
\left(Q_{p}\right) \text { in } \mathrm{m}^{3} / \mathrm{s} \text { using } \\
\text { original rainfall } \\
\text { data }\end{array}$ & $\begin{array}{l}\text { Peak discharge }\left(Q_{p}\right) \text { in } \\
\mathrm{m}^{3} / \text { s by considering } \\
10 \% \text { uncertainty of } \\
\text { rainfall }\end{array}$ \\
\hline Westside & 2.88 & 3.63 \\
Eastside & 2.24 & 2.48 \\
Southside & 9.6 & 10.56 \\
\hline
\end{tabular}

The proposed channel drainage area at the proposed location of the electric plant is shown in Figure 3(a). At this proposed location of the electric plant, the value of runoff coefficient (C) is taken as 0.9 by assuming that the road surface will use asphalt pavement. The comparison of calculated peak discharges using original rainfall data and by considering $10 \%$ uncertainty of rainfall based on 50-years return period using Log Pearson III probability distribution is presented at Table 2 .

After obtaining the value of design peak discharge for each perimeter drainages and each sub-channel drainage area, then the dimension of each drainage channel can be calculated.

The proposed drainage channels are south-west perimeter drainage channel, east perimeter drainage channel, collector A drainage channel, collector B drainage channel, collector $C$ drainage channel, and collector E drainage channel (see Figure 3(b)).

Table 2. Comparison of peak discharge values for the subchannel drainage area

\begin{tabular}{lll}
\hline $\begin{array}{l}\text { Sub-Channel } \\
\text { drainage } \\
\text { area }\end{array}$ & $\begin{array}{l}Q_{p}\left(\mathrm{~m}^{3} / \mathrm{s}\right) \\
\text { using original } \\
\text { rainfall data }\end{array}$ & $\begin{array}{l}Q_{p}\left(\mathrm{~m}^{3} / \mathrm{s}\right) \\
\text { by considering } 10 \% \\
\text { uncertainty of } \\
\text { rainfall data }\end{array}$ \\
\hline $\mathrm{A}_{1}=\mathrm{A}_{2}$ & 0.83 & 0.92 \\
$\mathrm{~B}_{1}=\mathrm{B}_{2}$ & 0.28 & 0.31 \\
$\mathrm{C}_{1}=\mathrm{C}_{2}$ & 0.32 & 0.35 \\
$\mathrm{D}_{1}=\mathrm{D}_{2}$ & 0.31 & 0.34 \\
$\mathrm{E}_{1}=\mathrm{E}_{2}$ & 0.91 & 1.00 \\
$\mathrm{~F}_{1}=\mathrm{F}_{2}$ & 0.41 & 0.45 \\
$\mathrm{G}_{1}=\mathrm{G}_{2}$ & 0.46 & 0.50 \\
\hline
\end{tabular}

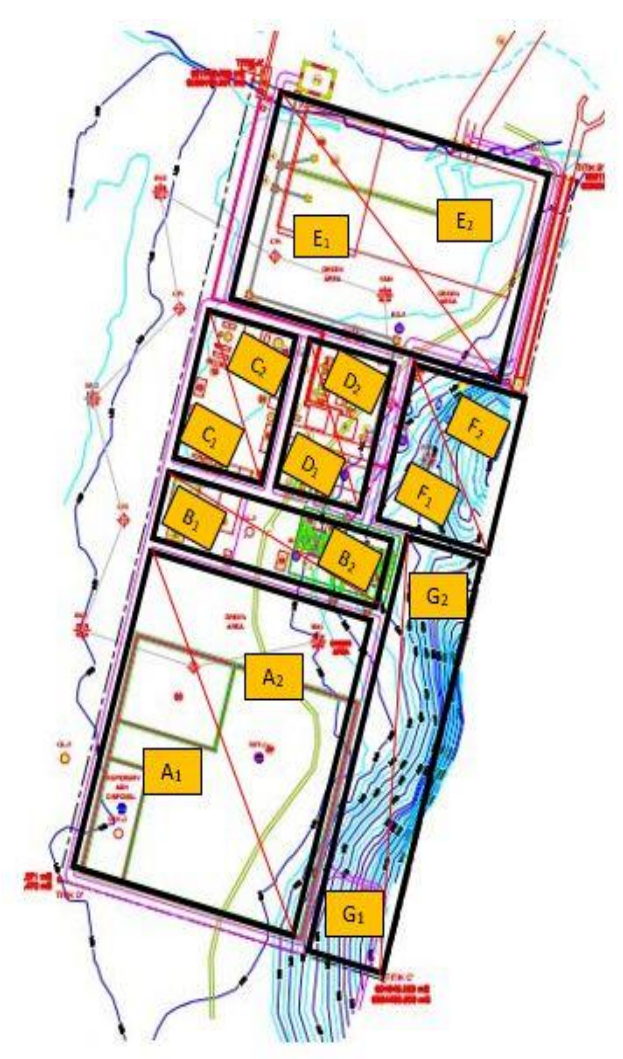

(a)

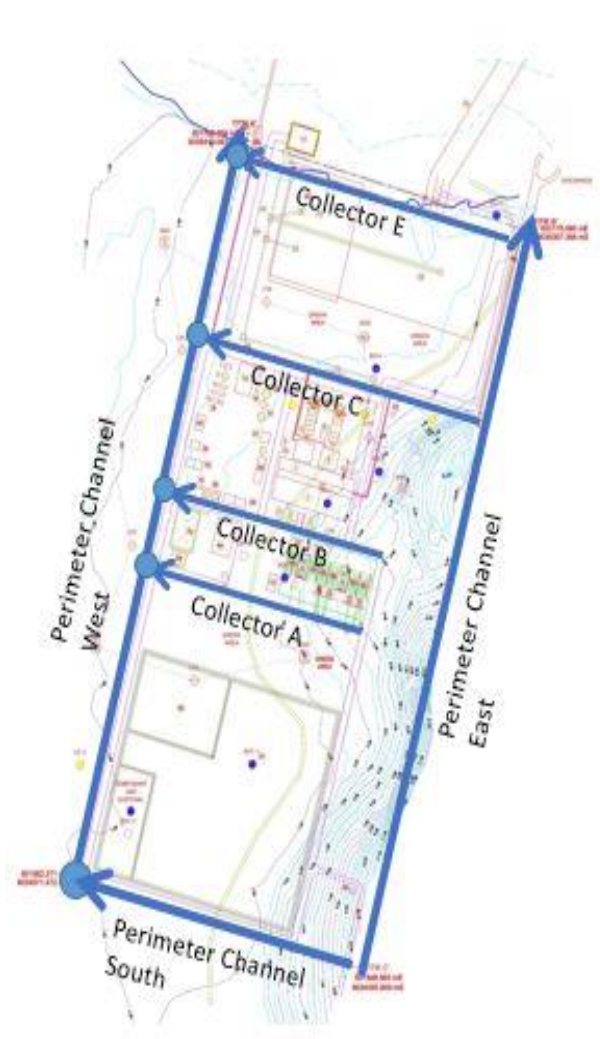

(b)

Figure 3. (a) Channel drainage area; (b) Proposed locations of drainage channels. 
The flows for south-west perimeter drainage channel and all of the collector channels are simulated using HEC-RAS software (see Figure 4), whereas the flow simulation for east perimeter drainage channel is presented in Figure 5.

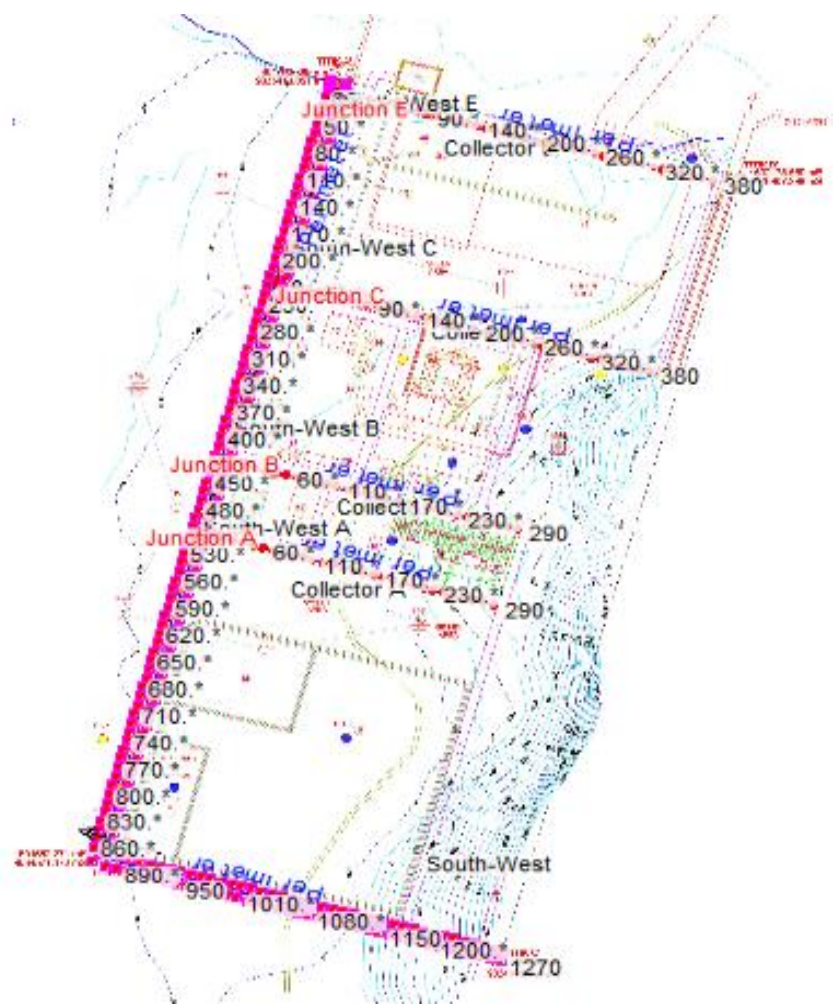

Figure 4. Flow simulation for south-west perimeter drainage channel and all of the collector-drainage channels.

The result of flow simulation is the dimension of the drainage channel. Figure 6 and Figure 7 showed the

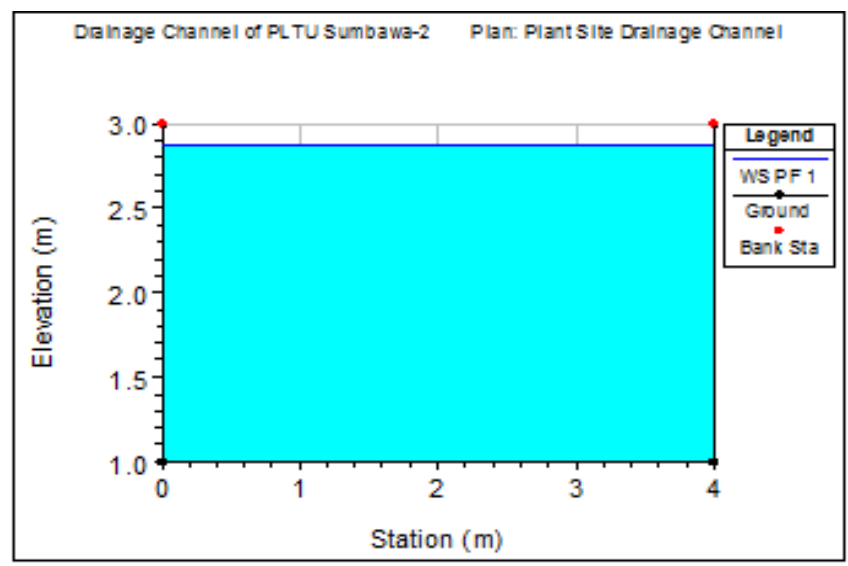

Figure 6. Cross section of south-west perimeter drainage channel using original rainfall data. simulation result of a cross-section of south-west perimeter drainage channel and cross section of collector A drainage channel based on calculated peak discharge using original rainfall data, respectively. Figure 8 and Figure 9 showed the simulation result of the Longitudinal section of south-west perimeter drainage channel and collector A drainage channel, respectively, based on calculated peak discharge using original rainfall data.

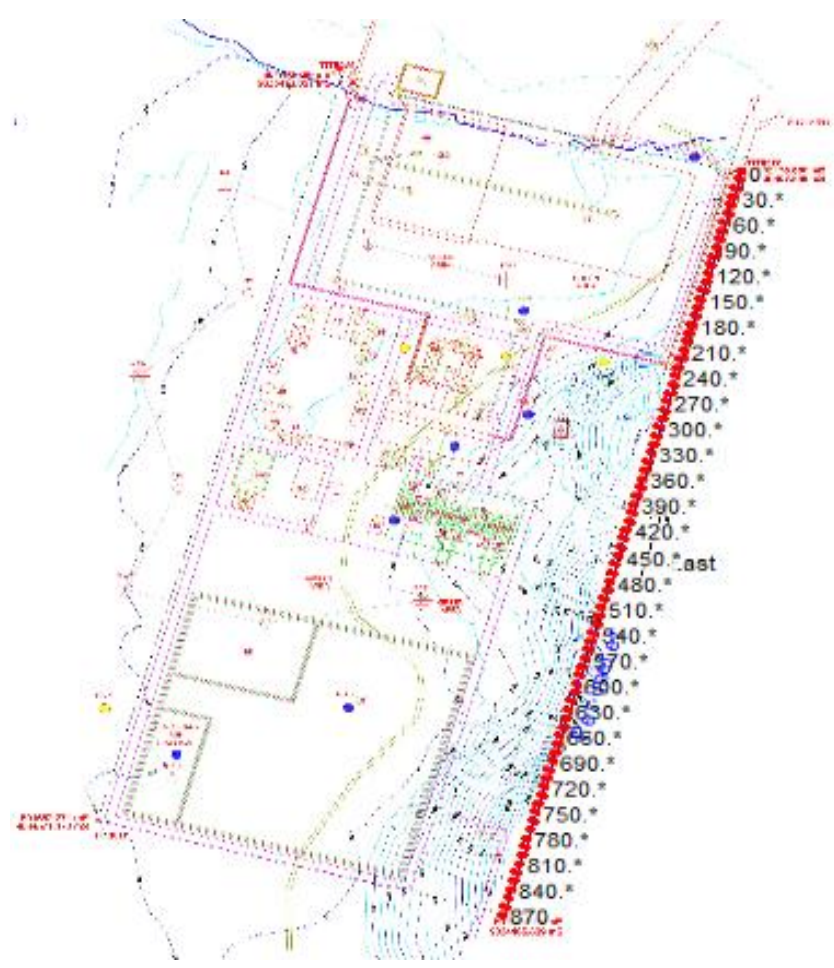

Figure 5. Flow simulation for east perimeter drainage channels.

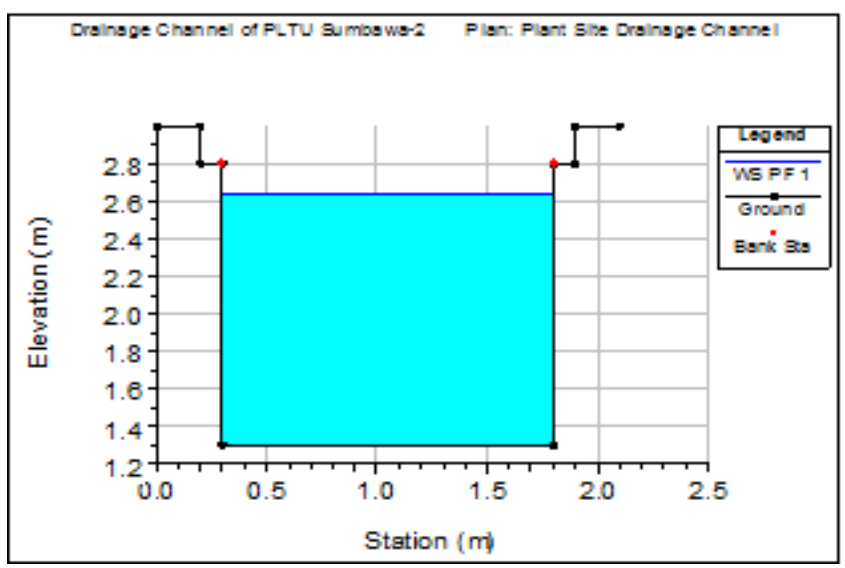

Figure 7. Cross section of collector A drainage channel using original rainfall data. 


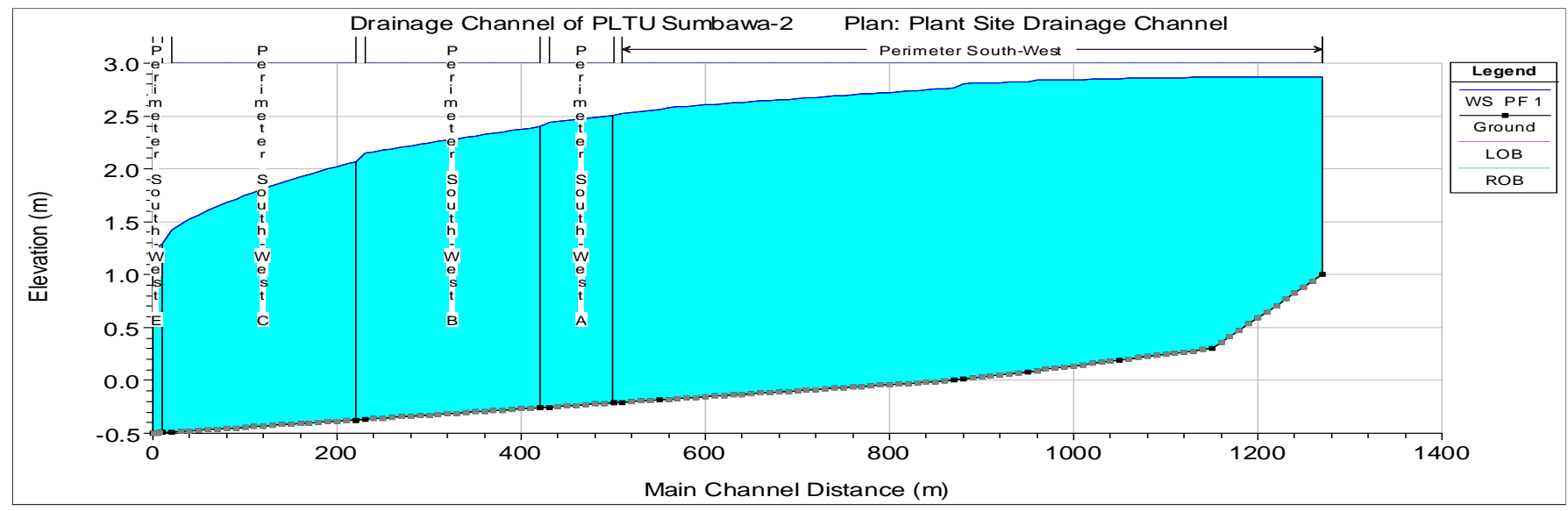

Figure 8. Longitudinal section of south-west perimeter drainage channel using original rainfall data.

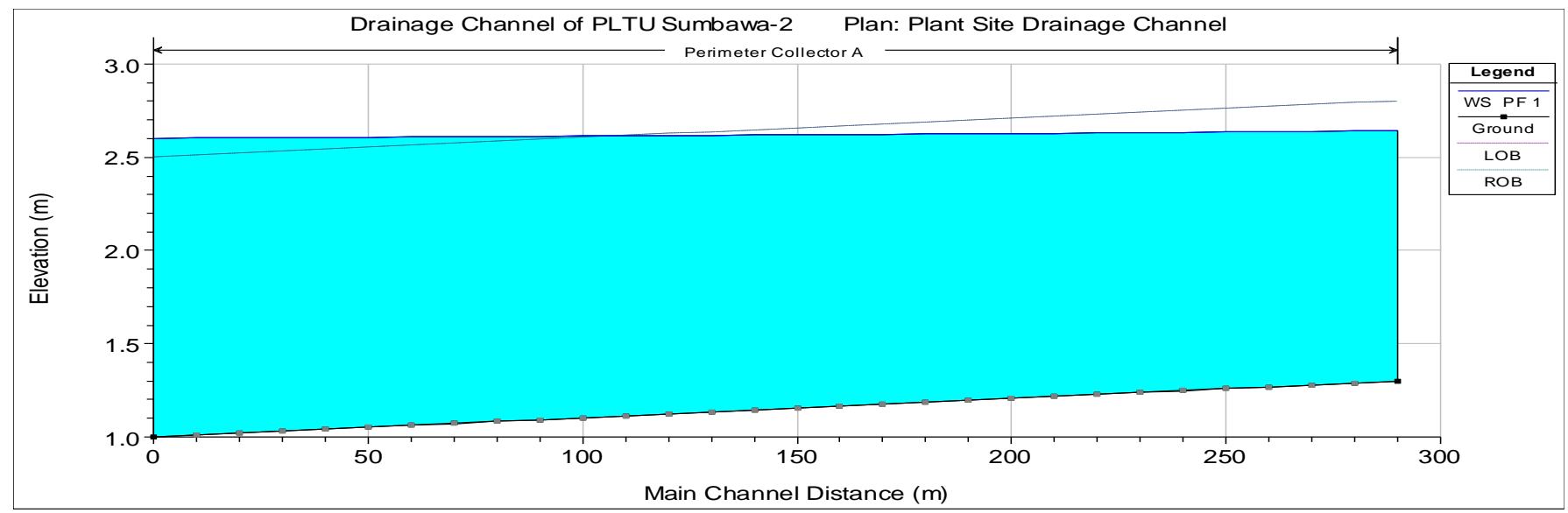

Figure 9. Longitudinal section of collector A drainage channel using original rainfall data.

The dimension and the elevation of each drainage channels are summarized in Table 3.

Table 3. Dimension an elevation of each drainage channels

\begin{tabular}{ccccc}
\hline Drainage channel & $\begin{array}{c}\text { Length } \\
(\mathrm{m})\end{array}$ & Width x Depth $\left(\mathrm{m}^{2}\right)$ & $\begin{array}{c}\text { Invert elevation } \\
\text { (upstream) }(\mathrm{m})\end{array}$ & $\begin{array}{c}\text { Invert elevation } \\
\text { (downstream) }(\mathrm{m})\end{array}$ \\
\hline $\begin{array}{c}\text { East perimeter } \\
\text { South-west perimeter }\end{array}$ & 870 & $1.5 \times 1.5$ & +1.3 & +0.5 \\
Collector A & 290 & $4 \times 3.5$ up to $4 \times 3.5$ & +1.0 & -0.5 \\
Collector B & 290 & $1.5 \times 1.5$ & +1.3 & +1.0 \\
Collector C & 380 & $1.5 \times 1.5$ & +1.3 & +1.0 \\
Collector E & 380 & $1.5 \times 1.5$ & +1.3 & +0.9 \\
\hline
\end{tabular}

The quantity of those drainage channels is presented in Table 4.

Table 4. The quantity of each drainage channels

\begin{tabular}{|c|c|c|c|c|c|c|c|}
\hline & $\begin{array}{c}\text { East } \\
\text { perimeter }\end{array}$ & $\begin{array}{c}\text { South } \\
\text { perimeter }\end{array}$ & $\begin{array}{c}\text { West } \\
\text { perimeter }\end{array}$ & $\begin{array}{c}\text { Collector } \\
\text { A }\end{array}$ & $\begin{array}{c}\text { Collector } \\
\text { B }\end{array}$ & $\begin{array}{c}\text { Collector } \\
\text { C }\end{array}$ & $\begin{array}{c}\text { Collector } \\
\text { E }\end{array}$ \\
\hline Reach length (m) & 870 & 400 & 870 & 290 & 290 & 380 & 380 \\
\hline $\begin{array}{l}\text { Length of junction } \\
\text { (m) }\end{array}$ & - & - & - & 10 & 10 & 10 & 10 \\
\hline Total length (m) & 870 & 400 & 870 & 300 & 300 & 390 & 390 \\
\hline $\begin{array}{l}\text { Channel dimension } \\
\qquad\left(\mathrm{m}^{2}\right)\end{array}$ & $1.5 \times 1.5$ & $4 \times 2.5$ & $4 \times 3$ & $1.5 \times 1.5$ & $1.5 \times 1.5$ & $1.5 \times 1.5$ & $1.5 \times 1.5$ \\
\hline Gates & - & 5 & 8 & - & - & - & - \\
\hline
\end{tabular}


Based on the quantity listed in Table 4, the estimated cost is shown in Table 5.

Table 5. Cost estimation

\begin{tabular}{|c|c|c|c|}
\hline & Quantity & Unit price & Cost (IDR) \\
\hline $\begin{array}{l}\text { Channel, } \\
\text { small } \\
\text { dimension } \\
(1.5 \times 1.5 \\
\left.\mathrm{m}^{2}\right)\end{array}$ & $\begin{array}{l}2,250 \\
{[\mathrm{~m}]}\end{array}$ & $4,500,000$ & $10,125,000,000$ \\
\hline $\begin{array}{l}\text { Channel, } \\
\text { large } \\
\text { dimension } \\
\left(4 \times 3 \mathrm{~m}^{2}\right)\end{array}$ & $\begin{array}{l}1,270 \\
{[\mathrm{~m}]}\end{array}$ & $13,500,000$ & $17,145,000,000$ \\
\hline Gates & $\begin{array}{l}13 \\
\text { stations }\end{array}$ & $36,000,000$ & $468,000,000$ \\
\hline & & Total cost & $27,738,000,000$ \\
\hline
\end{tabular}

Figure 10 showed that overflow is observed in the upper reach of South-West channel when 10\% uncertainty rainfall data is considered. The increase of water level in the South-West channel creates a backwater effect into the collector channels even though overflow does not occur in these channels.

After some run, a one-meter enlargement of channel width is required to avoid overflow in the South-West channel. Figure 11 depicts the water surface profile along the new $5 \times 3 \mathrm{~m}^{2}$ South-West channel under $10 \%$ uncertainty rainfall. The collector channels remain the same as the original dimension.

The above-estimated cost is for constructing drainage channel using the original rainfall data. The cost will be compared to the cost of constructing a drainage channel using uncertainty rainfall data. Figure 11 showed the simulation result of the longitudinal section of the south-west perimeter drainage channel based on calculated peak discharge using uncertainty rainfall data. Thus, after changing the dimension of south-west perimeter drainage channel from $4 \times 2 \mathrm{~m}^{2}$ to $5 \times 3 \mathrm{~m}^{2}$, flow happened due to $10 \%$ uncertainty of rainfall can be contained.

However, having modified the South-West channel and kept the collector channels the same, the cost escalation of the drainage channel can be deduced from the unit cost of $5 \times 3 \mathrm{~m}^{2}$ and $4 \times 3 \mathrm{~m}^{2}$ channels. If the unit cost is linear to the volume, the estimated cost escalation will be $25 \%$. The cost of the new large channel will increase by IDR 4,286,250,000. The total cost escalation is therefore $15 \%$ with respect to the cost of the original channel.

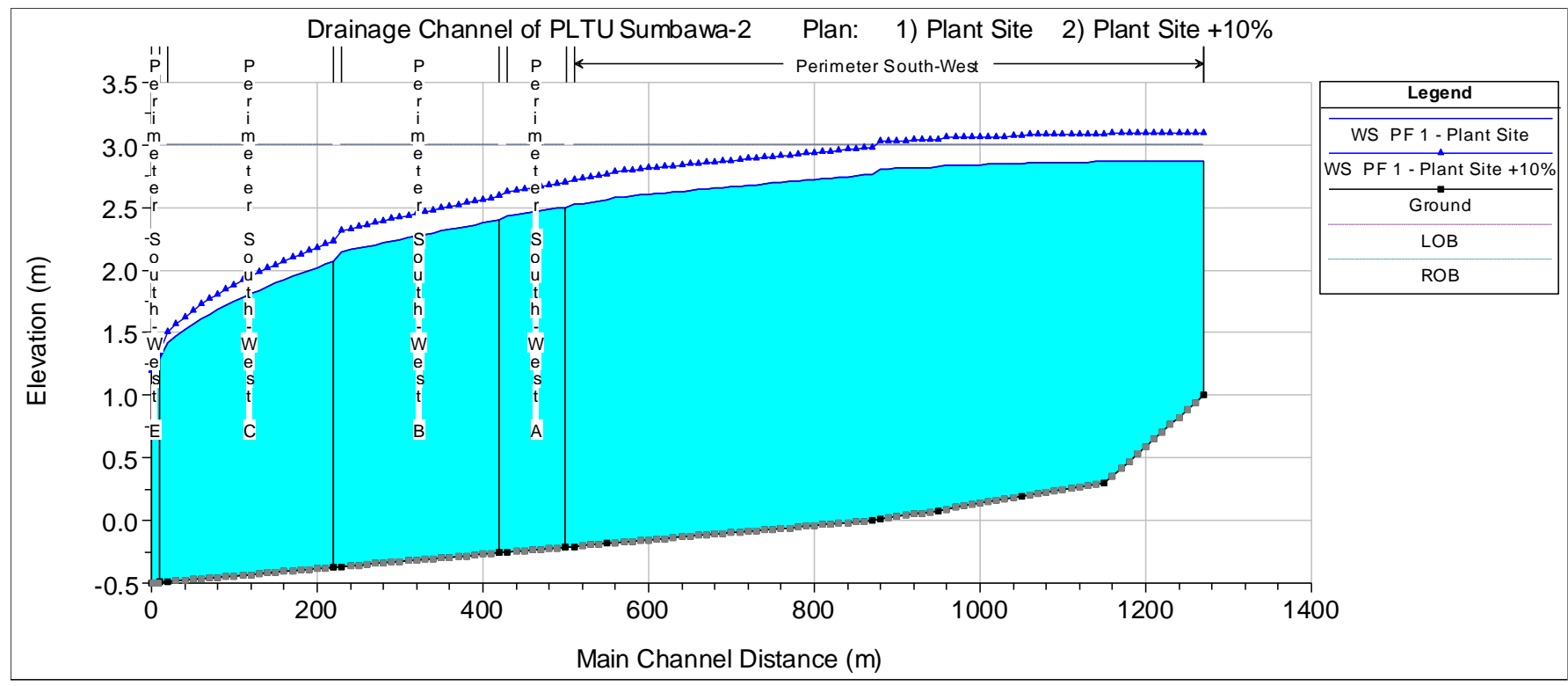

Figure 10. Longitudinal section of south-west perimeter drainage channel using uncertainty rainfall data. 


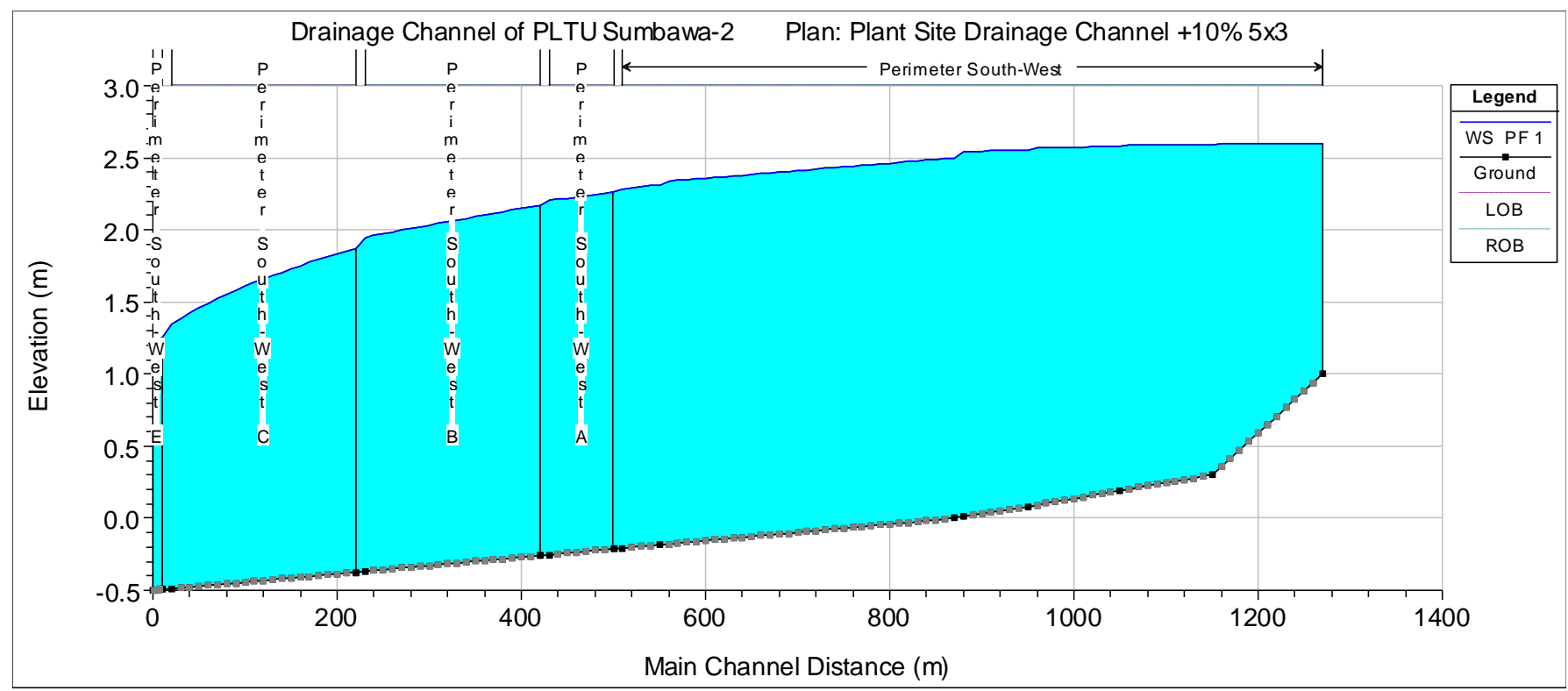

Figure 11. Longitudinal section of south-west perimeter drainage channel using uncertainty rainfall data after changing the channel dimension from $4 \times 2 \mathrm{~m} 2$ to $5 \times 3 \mathrm{~m}^{2}$.

\section{CONCLUSIONS}

Accurate rainfall data is the main input data for designing drainage channel. Previous studies showed observed rainfall data either by using rain gauges or by using radar contains $10 \%$ uncertainty. This study showed that the total cost to construct drainage channel increased by $15 \%$ if considering $10 \%$ uncertainty of rainfall. It is expected that this study can be useful for practitioners when designing drainage channel.

\section{REFERENCES}

Burcea, S. et al., 2012. Comparison Between Radar Estimated and Rain Gauge Measured Precipitation in The Modalvian Plateau. Environmental Engineering and Management Journal, pp. 723-731.
Cheval, S. et al., 2011. Climatologic Adjustments to Monthly Precipitation in Romania. International Journal of Climatology, pp. 704-714.

Lembaga Kerjasama Fakultas Teknik UGM, 2016. Studi Penyelidikan Lapangan PLTU Sumbawa 2 [Field Observation Study of PLTU Sumbawa 2] (2x50 MW), Yogyakarta.

Supraba, I., 2015. Uncertainty of Runoff Associate with Uncertainties of Water Holding Capacity and Rainfall Distribution in Mountainous Catchments. Hokkaido University.

Supraba, I. \& Yamada, T. J., 2015. Uncertainty of Peak Runoff Height Associated with Uncertainty of Water Holding Capacity and Rainfall Pattern. Journal of Japan Society of Civil Engineers, pp. I_17-I_22. 
[This page is intentionally left blank] 